\title{
Quality characteristics and antioxidant capacities of oriental melon wine depending on pretreatments
}

\author{
Hee-Young Hwang ${ }^{1}$, Hyoung-Tae $\mathrm{Ha}^{2}$, Se-Bi Ha ${ }^{2}$, Gi-Un Seong ${ }^{1}$, In-Wook Hwang ${ }^{3}$, \\ Shin-Kyo Chung ${ }^{1,3 *}$ \\ ${ }^{1}$ Department of Food Science and Technology, Kyungpook National University, Daegu 702-701, Korea \\ ${ }^{2}$ Hankook Wine Co., Ltd., Yeongcheon 770-803, Korea \\ ${ }^{3}$ Food and Bio-Industry Research Institute, Kyungpook National University, Daegu 702-701, Korea
}

\section{전처리 방법에 따른 참외와인의 품질특성과 항산화능}

\author{
황희영 ${ }^{1} \cdot$ 하형태 $^{2} \cdot$ 하세비 ${ }^{2} \cdot$ 성기운 $^{1} \cdot$ 황인욱 $^{3} \cdot$ 정신교 ${ }^{1,3 *}$ \\ ${ }^{1}$ 경북대학교 식품공학부, ${ }^{2}$ (주)한국와인, ${ }^{3}$ 경북대학교 식품생물산업연구소
}

\begin{abstract}
Oriental melon (Cucumis melo L. var. makuwa) has been widely consumed as various processed foods, such as dried products, jelly, wine, juice, and vinegar, in Asian countries. In fruit processing, blanching and pressure treatments affect its quality, such as antioxidant activities, sensory characteristics, and etc. This study was conducted to evaluate the effects of blanching and pressure pre-treatments on oriental melon wine-making (BP, blanching and pressure filtration; BNP, blanching and non-pressure filtration; NBP, non-blanching and pressure filtration; and NBNP, non-blanching and non-pressure filtration). Physicochemical properties and antioxidant capacities by a, a-diphenyl2-picrylhydrazyl (DPPH) radical scavenging activity, ferric ion reducing antioxidant power (FRAP) assay, and total phenolic and total flavonoid contents were measured for comparison of the different pre-treatment methods. After the aging process, the alcohol contents and $\mathrm{pH}$ values showed no statistical differences, whereas the amount of soluble solids, reducing sugar, and titratable acidity were slightly different among the pre-treatments $(p<0.05)$. The samples with blanching pre-treatment showed higher antioxidant capacities than those of other pre-treatments. In the sensory evaluation, the BNP was the best in overall acceptability. Thus, this study showed that the blanching treatment enhanced the antioxidant capacities and sensory qualities of the oriental melon wine.
\end{abstract}

Key words : antioxidant, blanching, oriental melon wine, pretreatment, quality

\section{서 론}

참외(Cucumis melo L. var. makuwa)는 박과에 속하는 1년 생 식물로써 여름철에 소비되고 있는 대표적인 과일이다. 최근 재배 기술의 발전에 따라 연중 생산되므로 농가소득에 큰 역할을 하고 있다(1). 참외는 비타민 함량이 높고 섬유질

*Corresponding author. E-mail : kchung@knu.ac.kr Phone : 82-53-950-5778, Fax : 82-53-950-6772

Received 12 March 2015; Revised 10 June 2015; Accepted 15 June 2015.

Copyright (c) The Korean Society of Food Preservation. All rights reserved.
이 풍부하여 변비에 도움을 주며 이뇨 작용에도 효과가 있다(2). 또한 진해와 거담에도 효과가 있고 항암성분인 cucurbitacin을 함유하고 있다(3). 그러나 조직이 쉽게 연화 되어 저장성이 떨어지기 때문에 과다출하 시기에는 수급조 절이 불안정하여 산지에서 상당한 양이 폐기되고 있다(4). 이러한 문제점을 해결하기 위해 건조제품(5), 젤리(6), 막걸 리(1), 주스(7), 식초(8) 등의 다양한 참외가공제품들이 개발 되고 있다.

최근 French paradox에 의하여 포도와인의 소비가 급증 하고 있으며, 이는 포도와인에 함유되어 있는 phytochemical 의 일종인 폴리페놀화합물이 각종 대사성 질환을 예방하는 기능을 가지고 있기 때문이다(9). 국내에서도 생활수준이 
향상되고 건강에 대한 관심이 증가하면서 포도 이외에도 살구(10), 수박(11) 복숭아(12) 등으로부터 와인이 개발되 고 있다.

과채류 가공을 위한 전처리 방법은 브랜칭, 착즙, 마이크 로웨이브 처리, 유기산 첨가 등이 있으며 제품의 품질과 보존성 향상을 위해 필수적이라고 할 수 있다(13). 특히 브랜칭 처리는 갈변효소의 억제 및 살균효과가 품질 향상과 유통기한을 연장하는 효과가 있으므로 포도주스(14), 포도 주(15), 대추와인(16)의 제조에 이용되고 있지만 영양소와 생리활성물질이 소실되는 단점이 있다(17-19). 또한 착즙은 과채류의 가공 수율을 높이며 제품의 이화학적 품질특성에 도 크게 영향을 미친다. 이에 양파즙(20), 포도주스(21), 오 디와인(22) 등의 제조 시 착즙 처리가 품질에 미치는 영향이 연구된 바 있다(23).

따라서 본 연구에서는 고품질 참외와인 제조를 위해 브 랜칭과 착즙 처리가 참외와인의 발효와 숙성에 따른 품질특 성과 항산화능에 미치는 영향을 조사하였기에 보고하는 바이다.

\section{재료 및 방법}

\section{실험 재료}

본 실험에 사용한 참외(Cucumis melo L. var. makuwa)는 경북 성주군에서 2014년 7월경에 수확한 오복 품종을 사용 하였으며, 효모는 Saccharomyces cerevisiae Fermivin dry yeast를 사용하였다. 참외는 6 일 동안 알코올 발효 후 4 주 숙성 후 품질특성을 분석하였다. 실험에 사용된 dinitrosalicylic acid(DNS), Folin-Ciocalteu's reagent, 1,1-diphenyl-2picryllhydrazyl(DPPH), 2,4,6-tris(2-pyridyl-s-triazine), 6-hydroxy2,5,7,8-tetramethylchromane-2-carboxylic acid, gallic acid, glucose, \pm catechin 은 Sigma사(Sigma Chemical Co., St. Louis, MO, USA)의 제품을 사용하였다.

\section{전처리 방법과 참외와인의 제조}

전처리 방법이 참외와인 제조 시 품질에 미치는 영향을 알아보기 위해 다음과 같은 방법으로 제조하였다. 처리구 별 참외 $10 \mathrm{~kg}$ 을 박피하지 않고 4등분 후 마쇄하여 참외 머스트를 제조하였다. 브랜칭 처리 및 착즙 처리가 와인 품질에 미치는 영향을 알아보기 위해 브랜칭 처리 (blanching)는 참외 머스트 표면에 끓는 물이 전체적으로 살포되도록 끓는 물과 참외 머스트를 소량씩 접촉시켜 $2 \%(\mathrm{v} / \mathrm{v})$ 처리 하였으며, 착즙 처리(pressure filtration)는 면포 를 이용하여 참외 머스트를 착즙, 1 차 발효가 끝난 후 착즙 처리를 하여 제조하였다. 비 브랜칭 처리는 위와 같은 브랜 칭 처리 과정을 생략하여 제조하였으며, 비 착즙 처리는 참외 머스트를 착즙하지 않고 면포를 통과하는 부분만 이용
하여 4가지 처리구(NBNP, non-blanching and non-pressure filtration; NBP, non-blanching and pressure filtration; BNP, blanching and non-pressure filtration; BP, blanching and pressure filtration)를 제조하였다. 이후 최종당도가 $24^{\circ} \mathrm{Brix}$ 가 되도록 설탕을 가하였으며, S. cerevisiae Fermivin dry yeast를 $0.02 \%$ 비활성 접종하여 $20^{\circ} \mathrm{C}$ 에서 6 일 동안 알코올 발효를 진행하였다. 모든 처리구에서 가용성 고형분 및 환 원당 함량 변화가 나타나지 않는 시점에 발효를 종료하고 $15^{\circ} \mathrm{C}$ 와인 저장고에서 4 주간 숙성 후 이화학적 특성 및 항산화능을 측정하였다.

\section{전처리 방법에 따른 발효 중 이화학적 특성}

가용성 고형분 함량은 굴절 당도계(N-1E, Atago, Tokyo, Japan)를 이용하여 측정하였으며, 환원당 함량은 DNS 비색 법(24)으로 측정하였다. 즉, 시료 $0.15 \mathrm{~mL}$ 에 DNS 시약 0.5 $\mathrm{mL}$ 를 넣고, water bath에서 5 분간 중탕한 후 증류수 3.5 $\mathrm{mL}$ 를 첨가하여 $550 \mathrm{~nm}$ 파장에서 흡광도를 측정(UV 1601, Shimadzu, Kyoto, Japan)하여 glucose equivalents(GE) g/100 $\mathrm{mL}$ 로 나타내었다. 적정 산도는 $\mathrm{AOAC}$ 방법(25)에 따라 0.1 $\mathrm{N} \mathrm{NaOH}$ 로 적정하여 citric acid 함량으로 나타내었으며, $\mathrm{pH}$ 는 $\mathrm{pH}$ meter(MP220, Mettler toledo Co., Switzerland)를 이용하여 측정하였다. 알코올 함량은 주류분석규정(26)에 따라 상징액 $100 \mathrm{~mL}$ 에 증류수 $30 \mathrm{~mL}$ 를 첨가하여 증류한 뒤 $70 \mathrm{~mL}$ 의 증류액을 받아 증류수 $30 \mathrm{~mL}$ 를 채워 주정계로 측정한 값을 Gay-Lussac 표를 이용해 $15^{\circ} \mathrm{C}$ 온도로 보정하여 환산하였다.

\section{항산화 활성 및 페놀화합물}

$\mathrm{DPPH}$ 라디칼 소거 활성은 Blois(27)의 방법에 따라 측정 하였다. 시료 $20 \mu \mathrm{L}$ 와 $100 \mu \mathrm{M} \mathrm{DPPH}$ 용액 $980 \mu \mathrm{L}$ 넣고 암실에서 30 분 방치한 다음 $520 \mathrm{~nm}$ 에서 흡광도를 측정하여 trolox equivalents(TE) $\mu \mathrm{M}$ 로 나타내었다. FRAP 활성은 Benzie 등(28)의 방법을 변용하여 측정하였다. 반응용액은 acetate buffer(pH 3.6, $300 \mathrm{mM}), 10 \mathrm{mM}$ TPTZ(2,4,6-tris (2-pyridyl-s-triazine)), $20 \mathrm{mM} \mathrm{FeCl}_{3} \cdot 6 \mathrm{H}_{2} \mathrm{O}$ 를 $10: 1: 1$ 비율로 혼합하여 $37^{\circ} \mathrm{C}$ 를 유지하면서, 시료 $25 \mu \mathrm{L}$ 에 반응용액 175 $\mu \mathrm{L}$ 를 혼합한 뒤 암실에서 30 분간 방치한 후, $590 \mathrm{~mm}$ 에서 흡광도를 측정하여 trolox equivalents(TE) $\mathrm{\mu M}$ 로 나타내었다.

총페놀성 화합물 함량은 Folin-Ciocalteu 방법(29)을 변용 하여 측정하였다. 즉 시료 $50 \mu \mathrm{L}$ 에 $2 \mathrm{~N}$ Folin-Ciocalteu's reagent $25 \mu \mathrm{L}$ 를 넣은 다음, $20 \% \mathrm{Na}_{2} \mathrm{CO}_{3} 150 \mu \mathrm{L}$ 를 가하여 15 분 동안 실온에서 방치하여 $725 \mathrm{~nm}$ 에서 흡광도를 측정하 여 gallic acid equivalents(GAE) $\mathrm{mg} / \mathrm{L}$ 로 나타내었다. 총플라 보노이드 함량은 $\mathrm{Jia}$ 등(30)의 방법을 변용하여 측정하였다. 시료 $70 \mu \mathrm{L}$ 에 $50 \% \mathrm{EtOH} 430 \mu \mathrm{L}$ 를 넣고 5\% sodium nitrite $50 \mu \mathrm{L}$ 를 혼합한 뒤 실온에서 5 분간 방치 후, $10 \%$ aluminum nitrate $50 \mu \mathrm{L}$ 를 넣고 실온에서 5 분 반응시킨 후 $1 \mathrm{~N} \mathrm{NaOH}$ 
$500 \mu \mathrm{L}$ 가한 다음 $510 \mathrm{~nm}$ 에서 흡광도를 측정하여 catechin equivalents(CE) $\mathrm{mg} / \mathrm{L}$ 로 나타내었다.

\section{기호적 특성}

기호적 특성은 경북대학교 식품공학부 학부 및 대학원생 15 명을 대상으로 색(color), 향(flavor) 맛(taste), 풋내(smell of green), 이취(odor), 종합적 기호도(overall acceptability)에 대하여 9점 척도법으로 평가 후 quantitative descriptive analysis(QDA) profile로 나타내었다.

\section{통계처리}

모든 실험 결과는 3 회 반복하여 실시하였고 그 결과 값을 평균과 표준편차로 표시하고(mean $\pm \mathrm{SD}), \mathrm{SAS}$ program (Statistical Analysis System, SAS Institute Inc., Cary, NC, USA)을 이용하여 분산분석과 Duncan's multiple range test $(\mathrm{p}<0.05)$ 를 실시하였다.

\section{결과 및 고찰}

\section{전처리 방법에 따른 발효 중 이화학적 특성}

전처리 방법에 따른 발효 중 이화학적 특성을 측정하였 다. 브랜칭 처리는 참외 머스트 대비 끓는 물을 $2 \%$ 첨가하였 고, 착즙 처리는 머스트 제조 후 착즙, 1 차 발효가 끝난 후 착즙하여 제조하였다. 전처리 방법에 따른 발효 중 가용 성 고형분, 환원당 함량은 Fig. 1과 2에서 보는 것과 같이 발효가 진행되는 동안 모든 처리구에서 가용성 고형분 함량 이 유의적으로 감소하였다. 발효가 끝나는 6일차에 가용성 고형분은 10.90 11.90\% 범위로 전처리에 방법에 따른 차이 가 나타나지 않았다. 환원당 함량은 발효 2일차 이후부터

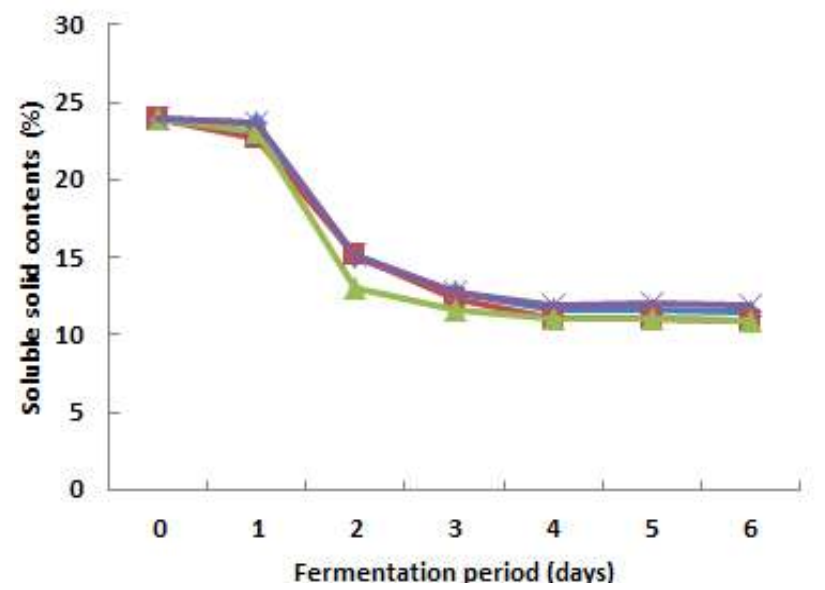

Fig. 1. Changes in the soluble solid content during fermentation of the oriental melon wine, depending on pretreatments.

$\operatorname{NBNP}(\checkmark)$, non-blanching and non-pressure filtration; $\operatorname{NBP}(\square)$, non-blanching and pressure filtration; $\operatorname{BNP}(\boldsymbol{\Lambda})$, blanching and non-pressure filtration; $\mathrm{BP}(\times)$, blanching and pressure filtration.

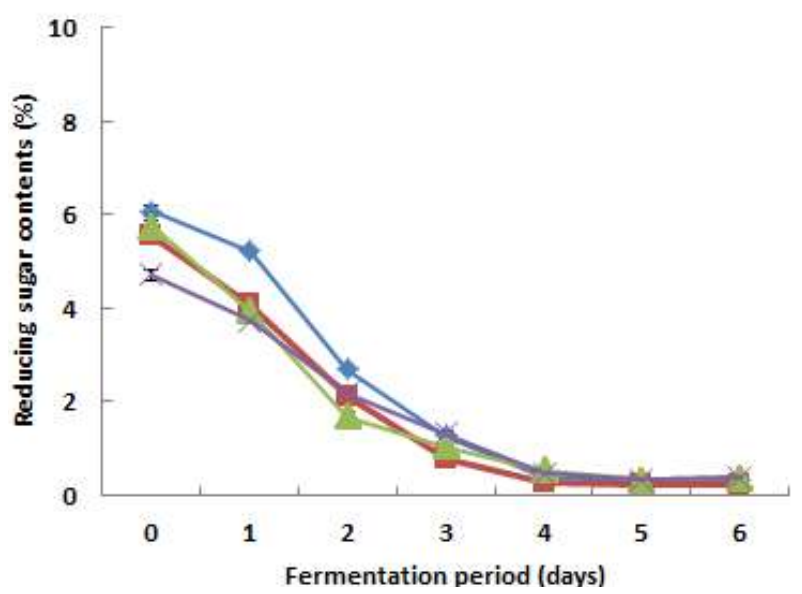

Fig. 2. Changes in the reduced sugar content during fermentation of the oriental melon wine, depending on pretreatments.

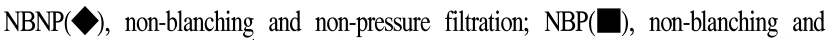
pressure filtration; $\operatorname{BNP}(\boldsymbol{\Lambda})$, blanching and non-pressure filtration; $\mathrm{BP}(\times)$, blanching and pressure filtration

급격히 감소하기 시작하여 발효 5 일차 이후 환원당 함량 변화가 나타나지 않았다. 발효 초기에는 브랜칭 처리구의 함량 감소가 컸으나 발효가 진행됨에 따라 비 브랜칭 처리 구의 함량 감소가 커져 발효가 종료되는 6 일차에는 $0.21 \sim 0.38 \mathrm{~g} / 100 \mathrm{~mL}$ 범위로 브랜칭 처리구에서 잔존하는 환원당 함량이 많게 나타났다. 이는 뜰보리수 과즙을 열처 리 후 와인을 제조하였을 때 환원당 함량이 많게 나타났다 는 연구결과와 일치하였다(31). 착즙에 따른 발효 중 환원당 함량 변화 차이는 나타나지 않았다. 전처리 방법에 따른 참외와인의 적정산도 및 $\mathrm{pH}$ 를 측정한 결과는 Fig. 3과 4에 나타내었다. 적정산도는 발효가 진행됨에 따라 모든 처리 구에서 5 일까지 증가하였다가 이후 다시 감소하는 경향을 보였다. 발효가 종료되는 6일차에는 $0.63 \sim 0.82 \%$ 범위로 포

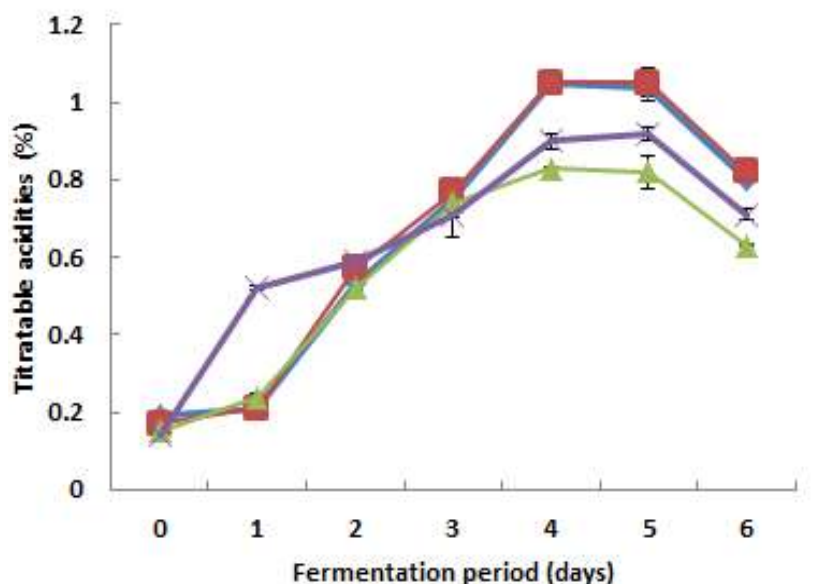

Fig. 3. Changes in titratable acidity during fermentation of the oriental melon wine, depending on pretreatments.

$\operatorname{NBNP}(\checkmark)$, non-blanching and non-pressure filtration; $\operatorname{NBP}(\square)$, non-blanching and pressure filtration; $\mathrm{BNP}(\boldsymbol{\Lambda})$, blanching and non-pressure filtration; $\mathrm{BP}(\times)$, blanching and pressure filtration. 


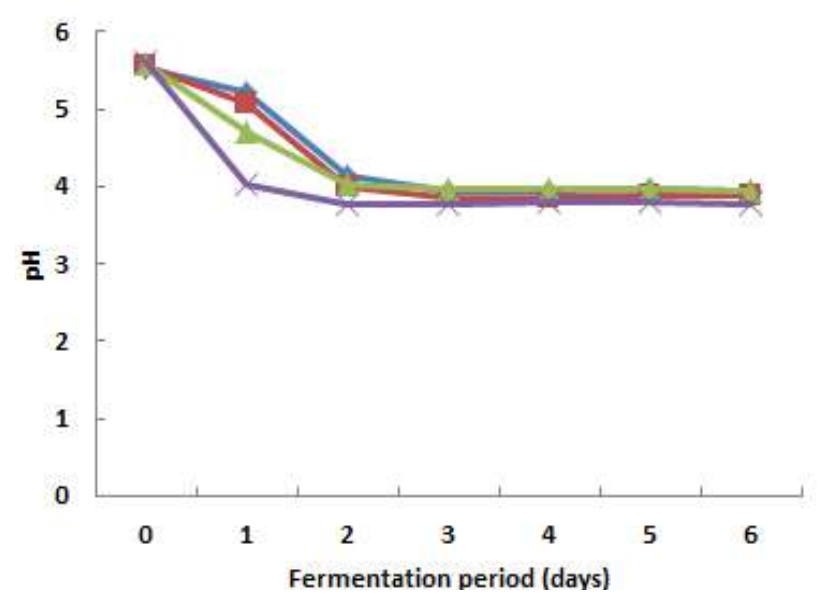

Fig. 4. Changes in the $\mathrm{pH}$ during fermentation of the oriental melon wine, depending on pretreatments.

$\operatorname{NBNP}(\boldsymbol{)})$, non-blanching and non-pressure filtration; $\operatorname{NBP}(\square)$, non-blanching and pressure filtration; $\mathrm{BNP}(\boldsymbol{\Lambda})$, blanching and non-pressure filtration; $\mathrm{BP}(\times)$, blanching and pressure filtration.

도 머스트를 열처리 하였을 때 적정산도에 영향을 미치지 않는다는 연구 결과와 유사하였다(15). $\mathrm{pH}$ 는 발효가 진행 됨에 따라 감소하였으며, 발효 마지막 6일차에 3.76 3.93 범위로 전처리 방법에 따른 차이가 나타나지 않았다. 이는 대추와인을 열처리 하였을 때 $\mathrm{pH}$ 의 차이가 나타나지 않는 다는 연구결과와 유사하였다(16). 전처리 방법에 따른 참외 와인의 알코올 함량 변화는 Fig. 5 에 나타내었다. 발효 2 일 차부터 알코올이 생성되기 시작하여 6 일 동안 유의적으로 알코올 함량이 증가 하였다. 전처리 방법 따른 유의적인 차이를 보였으며 $\mathrm{BNP}$ 에서 알코올이 가장 많이 생성된 것으 로 나타났다.

\section{참외와인의 숙성에 따른 이화학적 특성}

참외와인의 숙성에 따른 이화학적 특성 결과는 Table 1 과 같다. 이화학적 특성은 알코올 발효가 끝난 후 $15^{\circ} \mathrm{C}$ 와인 저장고에서 4주간 숙성 후 측정하였다. 알코올 함량은 숙성 전(11.7 12.5\%)과 비교하여 숙성 후(11.5 11.8\%) 함 량이 감소하였으며, 전처리 방법에 따른 함량 차이는 보이 지 않았다. 일반적인 와인의 알코올 함량은 9 14\% 범위가
적당하다고 보고되고 있으며(32), 제조한 와인은 11.5 $11.8 \%$ 범위의 알코올이 생성되었으며, 처리구 모두 적합한 알코올 생성을 보이는 것으로 나타났다. 가용성 고형분 함 량은 $10.7 \sim 11.2 \%$ 범위로 전처리 방법에 따른 차이가 나타 나지 않은 반면, 환원당 함량은 $0.25 \sim 0.49 \mathrm{~g} / 100 \mathrm{~mL}$ 범위로 브랜칭 처리구에서 유의적으로 높았다 $(\mathrm{p}<0.05)$. 적정 산도 는 각각 $0.60 \sim 0.81 \%, \mathrm{pH}$ 는 3.75 3.89 범위로 착즙처리 시 산도가 높고 $\mathrm{pH}$ 가 낮아지는 경향을 보였다. 이는 착즙 처리 로 인해 유기산이 더 많이 용출되어 이와 같은 결과를 보이 는 것으로 사료된다. 전반적으로 참외와인은 숙성 후 알코 올, 가용성 고형분, 환원당 함량, 적정산도가 숙성 전에 비하 여 함량이 감소하고 $\mathrm{pH}$ 는 증가하는 경향을 보였다.

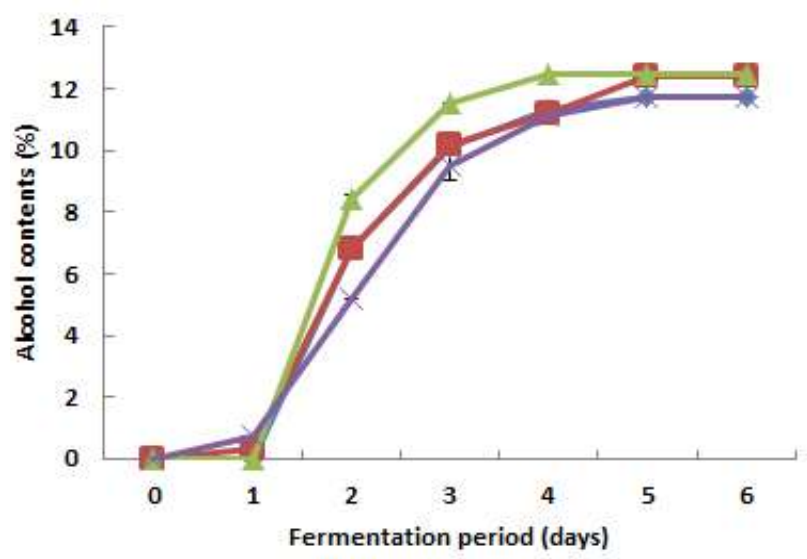

Fig. 5. Changes in the alcohol content during fermentation of the oriental melon wine, depending on pretreatments.

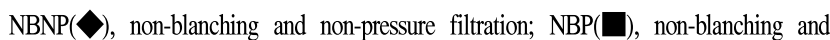
pressure filtration; $\mathrm{BNP}(\boldsymbol{\Lambda})$, blanching and non-pressure filtration; $\mathrm{BP}(\times)$, blanching and pressure filtration.

\section{항산화 활성 및 페놀화합물}

전처리 방법에 따른 참외와인의 항산화 활성 및 페놀화 합물 결과는 Table 2 와 같다. 참외와인의 $\mathrm{DPPH}$ 라디칼 소거 활성은 563.00 785.00 $\mu \mathrm{M} \mathrm{TE}$ 범위로 브랜칭 처리구의 활성 이 높았으며, 그 중 $\mathrm{BNP}$ 의 활성이 가장 높게 나타났다. FRAP 활성은 504.60 811.93 $\mu \mathrm{M}$ TE 범위로 DPPH 라디칼 소거 활성 결과와 유사하게 브랜칭 처리구의 활성이 높게

Table 1. The physicochemical qualities of the oriental melon wine after 4 weeks of aging, depending on the pretreatments

\begin{tabular}{cccccc}
\hline Samples ${ }^{1)}$ & $\begin{array}{c}\text { Alcohol contents } \\
(\%)\end{array}$ & $\begin{array}{c}\text { Soluble solid contents } \\
(\%)\end{array}$ & $\begin{array}{c}\text { Reducing sugar contents } \\
(\mathrm{g} / 100 \mathrm{~mL})\end{array}$ & $\begin{array}{c}\text { Titratable acidities } \\
(\%)\end{array}$ & $\mathrm{pH}$ \\
\hline NBNP & $11.5 \pm 0.0^{\mathrm{B} 2)}$ & $11.1 \pm 0.1^{\mathrm{A}}$ & $0.28 \pm 0.02^{\mathrm{B}}$ & $0.77 \pm 0.02^{\mathrm{B}}$ & $3.86 \pm 0.01^{\mathrm{B}}$ \\
NBP & $11.7 \pm 0.0^{\mathrm{AB}}$ & $10.8 \pm 0.1^{\mathrm{B}}$ & $0.25 \pm 0.02^{\mathrm{C}}$ & $0.81 \pm 0.01^{\mathrm{A}}$ & $3.84 \pm 0.01^{\mathrm{C}}$ \\
BNP & $11.8 \pm 0.2^{\mathrm{A}}$ & $10.7 \pm 0.1^{\mathrm{B}}$ & $0.42 \pm 0.01^{\mathrm{C}}$ & $0.60 \pm 0.00^{\mathrm{D}}$ & $3.89 \pm 0.01^{\mathrm{A}}$ \\
BP & $11.6 \pm 0.1^{\mathrm{AB}}$ & $11.2 \pm 0.1^{\mathrm{A}}$ & $0.49 \pm 0.01^{\mathrm{A}}$ & $0.67 \pm 0.01^{\mathrm{C}}$ & $3.75 \pm 0.01^{\mathrm{D}}$ \\
\hline
\end{tabular}

${ }^{1)} \mathrm{NBNP}$, non-blanching and non-pressure filtration; NBP, non-blanching and pressure filtration; BNP, blanching and non-pressure filtration; BP, blanching and pressure filtration.

${ }^{2)}$ Means followed by the same letters within the column per parameter are not significantly different $(p<0.05)$. 
Table 2. The antioxidant capacities of the oriental melon wine, depending on the pretreatments

\begin{tabular}{ccccc}
\hline Samples ${ }^{\mathrm{l}}$ & $\begin{array}{c}\text { DPPH } \\
(\mu \mathrm{M} \mathrm{TE})\end{array}$ & $\begin{array}{c}\text { FRAP } \\
(\mu \mathrm{M} \mathrm{TE})\end{array}$ & $\begin{array}{c}\text { Total phenolic contents } \\
(\mathrm{mg} / \mathrm{L})\end{array}$ & $\begin{array}{c}\text { Total flavonoid contents } \\
(\mathrm{mg} / \mathrm{L})\end{array}$ \\
\hline NBNP & $563.00 \pm 74.08^{\mathrm{C} 2)}$ & $504.60 \pm 25.06^{\mathrm{C}}$ & $312.08 \pm 9.53^{\mathrm{A}}$ & $39.06 \pm 5.30^{\mathrm{C}}$ \\
NBP & $585.67 \pm 47.43^{\mathrm{C}}$ & $506.60 \pm 58.28^{\mathrm{C}}$ & $304.62 \pm 4.39^{\mathrm{A}}$ & $52.85 \pm 5.50^{\mathrm{C}}$ \\
BNP & $785.00 \pm 31.43^{\mathrm{A}}$ & $701.93 \pm 11.02^{\mathrm{B}}$ & $303.18 \pm 4.51^{\mathrm{A}}$ & $78.30 \pm 6.40^{\mathrm{B}}$ \\
BP & $679.00 \pm 33.05^{\mathrm{B}}$ & $811.93 \pm 26.10^{\mathrm{A}}$ & $287.53 \pm 8.37^{\mathrm{B}}$ & $141.03 \pm 16.90^{\mathrm{A}}$ \\
\hline
\end{tabular}

${ }^{11} \mathrm{NBNP}$, non-blanching and non-pressure filtration; NBP, non-blanching and pressure filtration; BNP, blanching and non-pressure filtration; BP, blanching and pressure filtration.

${ }^{2)}$ Means followed by the same letters within the column per parameter are not significantly different $(p<0.05)$.

나타났으며, 그 중 $\mathrm{BP}$ 의 활성이 가장 높았다. 이는 뜰보리수 과즙을 열처리 후 와인을 제조하였을 때 항산화 활성이 증가하였다는 연구결과와 일치하였다(31). 총페놀성 화합 물 함량은 각각 $\mathrm{NBNP}(312.08 \mathrm{mg} / \mathrm{L}), \mathrm{NBP}(304.62 \mathrm{mg} / \mathrm{L})$, $\mathrm{BNP}(303.18 \mathrm{mg} / \mathrm{L}), \mathrm{BP}(287.53 \mathrm{mg} / \mathrm{L})$ 로 $\mathrm{BP}$ 를 제외한 나머 지 처리구에서는 유의적인 차이가 나타나지 않았다 $(\mathrm{p}<0.05)$. 총플라보노이드 함량은 각각 $\mathrm{BP}(141.03 \mathrm{mg} / \mathrm{L})$, $\mathrm{BNP}(78.30 \mathrm{mg} / \mathrm{L}), \mathrm{NBP}(52.85 \mathrm{mg} / \mathrm{L}), \mathrm{NBNP}(39.06 \mathrm{mg} / \mathrm{L})$ 순 으로 많게 나타났으며, 브랜칭 처리구의 함량이 유의적으 로 많은 것으로 나타났다(p<0.05). 과채류를 열처리할 경우 세포막과 세포벽이 붕괴되고 ester 결합으로 이루어진 결합 형 폴리페놀이 유리형으로 전환되어 항산화능이 증가한다 고 보고된 바 있다(31).

\section{기호적 특성}

전처리 방법에 따른 참외와인의 기호적 특성 결과는 Fig. 6에서 보는바와 같이 QDA profile로 나타내었다. QDA profile은 제품의 관능적 특성을 보다 정확히 나태내기 위해 개발된 정량적 분석방법이며(33), 벌꿀와인(34), 자두와인 (35), 배 막걸리(36) 등의 주류에 적용된 바 있다. 색 항목에 서는 4가지 처리구 중 $\mathrm{BNP}, \mathrm{BP}$ 가 6.33으로 가장 높은 점수

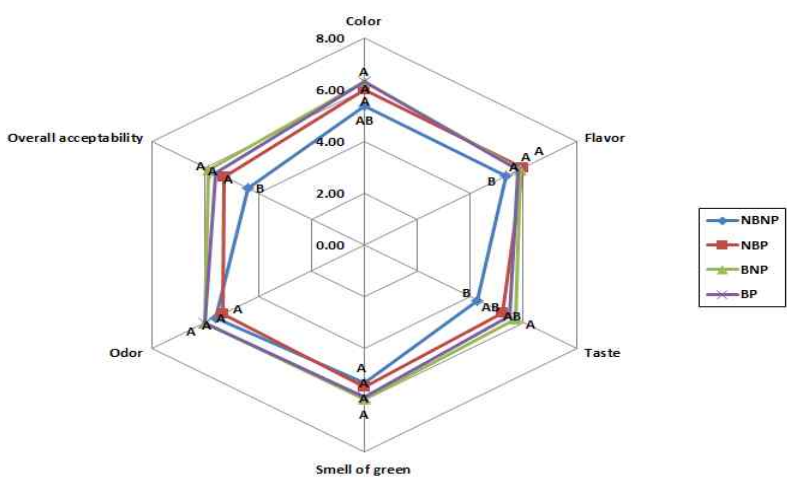

FIg. 6. QDA profile of the sensory qualities of the oriental melon wine, depending on pretreatments.

$\operatorname{NBNP}(\downarrow)$, non-blanching and non-pressure filtration; $\operatorname{NBP}(\boldsymbol{\square})$, non-blanching and pressure filtration; $\mathrm{BNP}(\boldsymbol{\Lambda})$, blanching and non-pressure filtration; $\mathrm{BP}(\times)$, blanching and pressure filtration. Means $(\mathrm{n}=15)$ with different letters above a bar are significantly different at $p<0.05$. Nine point hedonic scale (1=extremely dislike, $5=$ dislike \& like, $9=$ extremely like)
를 얻은 반면, NBNP가 5.40으로 가장 낮은 점수를 얻었다. 향의 경우에는 NBP가 6.0 으로 가장 높은 점수를 얻었다. 맛과 풋내 항목에서는 $\mathrm{BNP}$ 가 가장 높은 점수를 얻었으며, $\mathrm{NBNP}$ 가 가장 낮은 점수를 얻었다. 이취와 종합적 기호도 항목에서도 $\mathrm{BNP}, \mathrm{BP}$ 가 가장 높은 점수를 얻은 반면, $\mathrm{NBNP}$, $\mathrm{NBP}$ 가 가장 낮은 점수를 얻었다. 전반적으로 브랜칭 처리 구가 비 브랜칭 처리구에 비해 기호적으로 우수한 평가를 받는 것으로 보아, 브랜칭 처리가 참외와인의 색을 개선시 키며, 참외 특유의 풋내와 이취를 억제하는데 효과적인 것 으로 사료된다.

\section{요 약}

고품질 참외와인을 제조하기 위하여 브랜칭 및 착즙 처 리를 하여 발효와 숙성에 따른 이화학적 특성 및 항산화능 을 조사하였다. 발효 중 참외와인의 이화학적 특성은 모든 처리구가 유사한 추이를 보였으며, 브랜칭 및 착즙 처리가 알코올 발효에 영향을 미치지 않았다. 숙성 후 이화학적 특성을 측정한 결과는 알코올 함량, 가용성 고형분 함량, 환원당 함량, 적정 산도, $\mathrm{pH}$ 가 각각 $11.5 \sim 11.8 \%, 10.7$ $11.2 \%, 0.25 \sim 0.49 \mathrm{~g} / 100 \mathrm{~mL}, 0.60 \sim 0.81 \%, 3.75 \sim 3.89$ 범위로 나타났으며, 숙성 전에 비하여 가용성 고형분, 환원당, 알코 올 함량, 적정산도는 감소하고 $\mathrm{pH}$ 는 증가하는 것으로 나타 났다. 항산화능은 DPPH 라디칼 소거 활성, FRAP 활성이 각각 563.00 785.00 $\mu \mathrm{M} \mathrm{TE}, 504.60 \sim 811.93 \mu \mathrm{M} \mathrm{TE}$ 범위로 나타났으며, 브랜칭 처리구의 항산화 활성이 높았다. 총페 놀성 화합물 함량은 $287.53 ~ 312.08 \mathrm{mg} / \mathrm{L}$ 범위로 전처리 방법에 따른 유의적인 차이가 나타나지 않았으며 $(\mathrm{p}<0.05)$, 총플라보노이드 함량은 $39.06 ~ 141.03 \mathrm{mg} / \mathrm{L}$ 범위로 브랜칭 처리구의 함량이 높았다. 또한 QDA profile 결과는 색, 맛, 풋내, 이취, 종합적 기호도 항목에서 모두 브랜칭 처리구가 더 높은 점수를 얻었다. 브랜칭 처리는 참외와인의 항산화 능을 증가시키고 기호성을 좋게 하는 반면, 착즙 처리는 참외와인 제조 시 영향을 미치지 않는 것으로 나타났다. 


\section{감사의 글}

본 연구는 대구경북 지방중소기업청이 지원하는 경북지 역 바이오중소기업을 위한 기술개발 지원사업의 지원으로 수행되었습니다.

\section{References}

1. Kim TY, Kim SB, Kim JS, Lee SH (2006) Properties of Oriental melon wine developed by utilizing rice wine fermentation method. J Korean Soc Appl Biol Chem, 49, 125-130

2. Yoon HS, Oh MJ, Choi C (1983) Studies on the development of food resources from waste seeds. J Korean Soc Appl Biol Cheml, 26, 163-168

3. Shin YS, Lee JE, Yeon IK, Do HW, Cheung JD, Kang CK, Choi SY, Youn SJ, Cho JG, Kwoen DJ (2008) Antioxidant and antimicrobial effects of extract with water and ethanol of Oriental melon (Cucumis melo $\mathrm{L}$. var makuwa Makino). J Korean Soc Appl Biol Chem, 51, 194-199

4. Kim TY, Lee SH, Kim JK, Kim SB (2006) Pretreatment and storage condition abnormal fermented Oriental melon for fermentation use. J Korean Soc Appl Biol Chem, 49, 202-208

5. Kim JG, Jeong ST, Jang HS, Kim YB (1997) Quality properties of dried melon with different pretreatment. Korean J Post-Harvest Sci Technol Agri Products, 4, $147-153$

6. Lee GD, Yoon SR, Lee MH (2004) Monitoring of organoleptic and physical properties on preparation of Oriental melon jelly. J Korean Soc Food Sci Nutr, 33, 1373-1380

7. Lee GD, Kwon SH, Lee MH, Kim SY, Joo GJ, Kwon $\mathrm{JH}$ (2004) Change of organoleptic properties with heating concentration of Oriental melon juice. Korean J Food Preserv, 11, 130-133

8. Lee GD, Kin SK, Lee MH (2005) Quality change of beverage containing muskmelon vinegar and concentrated muskmelon juice during storage. Korean J Food Preserv, 12, 223-229

9. Hosu A, Cristra VM, Cimpoiu C (2014) Analysis of total phenolic, flavonoids, anthocyanins and tannins content in romanian red wines : prediction of antioxidant activities and classification of wines using artificial neural networks. Food Chem, 150, 113-118
10. Jung GT, Ju IO, Ryu J, Choi JS, Choi YG (2003) Studied on manufacture of wine using apricot. Korean J Food Preserv, 10, 493-497

11. Park CS, Kim ML (2010) Preparation and characterization of watermelon wine. Korean J Food Preserv, 17, 547-554

12. Park HS (2010) Characteristics of peach wine with different commercial yeast strains. J East Asian Soc Dietay Life, 20, 531-535

13. Kim KI, Hwang IG, Yoo SM, Min SG, Choi MJ (2014) Effects of various pretreatment methods on physicochemical and nutritional properties of carrot. J Korean Soc Food Sci Nutr, 43, 1881-1888

14. Cabera SG, Jang JH, Moon KD (2009) Quality and functional properties of juice from different grape varieties as functions of heating time and temperature. Korean J Food Preserv, 16, 463-471

15. Chang EH, Jeong ST, Roh JH, Jeong SM, Lee HC, Choi JU (2010) Wine quality properties with reference to the temperature of grape-must prior to fermentation. Korean J Food Preserv, 17, 608-615

16. Min YK, Lee MK, Yoon HS, Park HJ (1997) Quality changes in jujube wine with heating temperatures. Food Eng Prog, 1, 212-218

17. Kim HY, Woo KS, Hwang IG, Lee YR, Jeong HS (2008) Effects of heat treatments on the antioxidant activities of fruits and vegetables. Korean J Food Sci Technol, 40, 166-170

18. Yildiz F, Westhoff D (1995) Associative growth of lactic acid bacteria in cabbage juice. J Food Sci, 46, 962-963

19. Kaiser A, Kammerer, DR, Carle R (2013) Impact of blanching on polyphenol stability and antioxidant capacity of innovative coriander (Coriandrum sativum L.) pastes. Food Chem, 140, 332-339

20. Choi BG, Surh JH (2014) Effects of heat treatment on the quality of the onion juices prepared with sulfurapplied onions. Korean J Food Sci Technol, 46, 189-197

21. Kim JS, Kim SH, Lee WK, Pyun JY, Yook C (1999) Effects of heat treatment on yield and quality of grape juice. Korean J Food Sci Technol, 31, 1397-1400

22. Choi JH, Kim KY, Lee JC (1998) Effects of pre-pressing condition on quality of pear juice. Korean J Food Sci Technol, 30, 827-831

23. Kim KI, Kim ML (2010) Characteristics of wine fermented from mulberry juice. Korean J Food Preserv, $17,563-570$

24. Miller GL (1959) Use of dinitrosalicylic acid reagent for determination of reducing sugar. Anal Chem, 31, 
426-428

25. AOAC (2000) Official Methods of Analysis 17th ed. Association of official analytical chemists. Washington DC, USA

26. Hwang SW, Park HD (2009) Characteristics of red wine fermentation of freeze-concentrated campbell early grape juice using various wine yeasts. Korean J Food Preserv, 16, 977-984

27. Blois MS (1958) Antioxidants determination by the use of a stable free radical. Nature, 182, 1199-1200

28. Benzie IFF, Strain JJ (1996) The ferric reducing ability of plasma as a measure of antioxidant power, the FRAP assay. Anal Biochem, 239, 70-76

29. Singleton VL, Orthofer R, Lamuela-Raventos RM (1999) Analysis of total phenolic and other oxidation substrates and antioxidants by means of Folin-Ciocalteu reagents. Methods Enzymol, 299, 152-178

30. Jia Z, Tang M, Wu J (1999) The determination of flavonoid contents in mulberry and their scavenging effects on superoxide radicals. Food Chem, 64, 555-599
31. Cho KM, Joo OS (2014) Quality and antioxidant characteristics of Elaeagnus multiflora wine through the thermal processing of juice. Korean J Food Preserv, 21, 206-214

32. Cho KM, Lee JB, Kahng GG, Seo WT (2006) A study on the making of sweet persimmon (Diospyros kaki T.) wine. Korean J Food Sci Technol, 38, 785-792

33. Stone H, Sidel.JL, Bloomquist.JL (1980) Quantitative descriptive analysis. Cereal Foods World, 25, 642

34. Lee DH, Kang HY, Lee YS, Cho CH, Park IT, Kim HD, Lim JW (2012) Brewing and quality characteristics of Korean honey wine (Mead) with a variety of honey and yeast. Korean J Food Sci Technol, 44, 736-742

35. Seo SB, Han SM, Kim JH, Kim NM, Lee JS (2001) Manufacture and physiological functionality of wines and liquors by using plum (Prunus salicina). Korean J Biotechnol Bioeng, 16, 153-157

36. Lee DH, Kim JH, Lee JS (2009) Effect of pears on the quality and physiological functionality of Makgeoly. J Korean Soc Food Sci Nutr, 22, 606-611 